\title{
Photoelectrochemical sensing of hydrogen peroxide on hematite
}

\author{
Hiba Saada, ${ }^{[a, b]}$ Rawa Abdallah, ${ }^{[b]}$ Jean-François Bergamini, ${ }^{[a]}$ Stéphanie Fryars, ${ }^{[a]}$ Vincent Dorcet, ${ }^{[a]}$ \\ Loic Joanny, ${ }^{[a]}$ Francis Gouttefangeas, ${ }^{[a]}$ Sophie Ollivier, ${ }^{[a]}$ Gabriel Loget ${ }^{*}[a]$
}
[a] H. Saada, Dr. J.-F. Bergamini, S. Fryars, Dr. V. Dorcet, L. Joanny, F. Gouttefangeas, S. Ollivier, Dr. G. Loget
Univ Rennes, CNRS, ISCR (Institut des Sciences Chimiques de Rennes)-UMR6226 - ScanMAT-UMS2001, F-35000 Rennes, France
E-mail: gabriel.loget@univ-rennes1.fr

[b] Dr. Rawa Abdallah

Lebanese University, EDST, AZM Center for Research in Biotechnology and Its Applications, Laboratory of Applied Biotechnology, LBA3B, EI Mitein Street, Tripoli, Lebanon

Supporting information for this article is given via a link at the end of the document.

\begin{abstract}
Due to its abundance and chemical stability, hematite $(\alpha-$ $\mathrm{Fe}_{2} \mathrm{O}_{3}$ ) is a promising $n$-type semiconductor photoelectrode. This is particularly true in the frame of the rapidly developing area of photoelectrochemical (PEC) sensing, where the short excited-state lifetime and the small carrier diffusion length of hematite can be beneficially employed. On the other hand, $\mathrm{H}_{2} \mathrm{O}_{2}$ is an essential molecule for biological, environmental and industrial applications. In this article, we report a simple method to prepare photoelectroactive hematite layers on fluorine-doped $\mathrm{SnO}_{2}$ (FTO) and we use these surfaces for $\mathrm{H}_{2} \mathrm{O}_{2}$ PEC sensing. The so-created sensors allow to reliably detect $\mathrm{H}_{2} \mathrm{O}_{2}$ down to a sub- $\mu \mathrm{M}$ concentration with a large linear range and a good reusability.
\end{abstract}

$\mathrm{H}_{2} \mathrm{O}_{2}$ is a crucial molecule. First, it is a marker for oxidative stress and a major factor of pathophysiological complications in serious diseases. ${ }^{[1,2]} \mathrm{H}_{2} \mathrm{O}_{2}$ is also present in the natural environment ${ }^{[3]}$ and commonly employed as a reagent in paper, textile or food industry. Hence, fast and accurate monitoring of $\mathrm{H}_{2} \mathrm{O}_{2}$ is of great interest to medicine, environmental and industrial processing. Analytical protocols based on chromatography, ${ }^{[4]}$ titration, ${ }^{[5]}$ spectrophotometry, ${ }^{[6]}$ fluorescence, ${ }^{[7]}$ chemiluminescence, ${ }^{[8]}$ and electrochemistry ${ }^{[9,10]}$ have been used to detect this molecule and the development of $\mathrm{H}_{2} \mathrm{O}_{2}$ sensors attracts considerable attention. ${ }^{[9,11]}$ Photoelectrochemical (PEC) sensing is based on the photoinduced charge transfer at a semiconductor/liquid interface. It is a rather new and rapidly-developing research area which sensing combines aspects of electrochemical and optical sensing. ${ }^{[12,13]}$ PEC sensing decouples excitation (light) and detection (electrochemical) signals, which is expected to significantly increase the signal-to-noise ratio with respect to electrochemical sensing. ${ }^{[13]}$ Besides, it is also promising because it enables $2 \mathrm{D}$ reaction confinement on the transducer surface (i.e. on the photoelectrode $)^{[14,15]}$ which can be useful for electrode reuse ${ }^{[16,17]}$ or for the design of multiplexed arrays. ${ }^{[18,19]}$ So far, PEC sensing has been mainly employed for the detection of biological macromolecules, ${ }^{[20]}$ in immuno-[21] or apta-[22] assays and has also been explored for the detection of small organic molecules such as antioxidants ${ }^{[23]}$ or glucose. ${ }^{[24,25]}$ While $\mathrm{H}_{2} \mathrm{O}_{2}$ is a widelyemployed hole scavenger in the field of energy-related photoelectrochemical research (typically used to probe the upper performance of water-splitting photoanodes), ${ }^{[26,27]}$ the PEC sensing of $\mathrm{H}_{2} \mathrm{O}_{2}$ has been only reported on $\mathrm{TiO}_{2},{ }^{[28-30]} \mathrm{WO}_{3},{ }^{[31]}$ $\mathrm{ZnO},{ }^{[32,33]} \mathrm{BiVO}_{4},{ }^{[34,35]}$ and $\mathrm{Si}^{[36]}$-based photoanodes and on $\mathrm{Cu}_{2} \mathrm{O},{ }^{[37]} \mathrm{CuO},{ }^{[38]} \mathrm{CdS},{ }^{[39]}$ and $\mathrm{CulnS}_{2}{ }^{[40]}$-based photocathodes.
Hematite $\left(\alpha-\mathrm{Fe}_{2} \mathrm{O}_{3}\right)$ is a promising photoanode material due to its great abundance, low-cost, chemical stability and its high theoretical photoconversion efficiency. ${ }^{[41,42]}$ Nevertheless, it also has a short excited-state lifetime and a small hole diffusion length. This is a severe drawback for energy-related application s $^{[41,42]}$ but can be a great advantage for the design of PEC sensor arrays activated by micrometer-sized spots of light. ${ }^{[15,17]}$ Hematite photoanodes have been previously employed for the PEC sensing of biological macromolecules, ${ }^{[43,44]}$ neurotransmitters, ${ }^{[17]}$ endocrine disruptors, ${ }^{[45,46]}$ glucose, ${ }^{[25,44]}$ inorganic pollutants, ${ }^{[47]}$ and metal cations. ${ }^{[48]}$ In this paper, we report the preparation of hematite photoanodes by a convenient spin-coating/annealing method and the use of these surfaces for $\mathrm{H}_{2} \mathrm{O}_{2}$ PEC sensing.
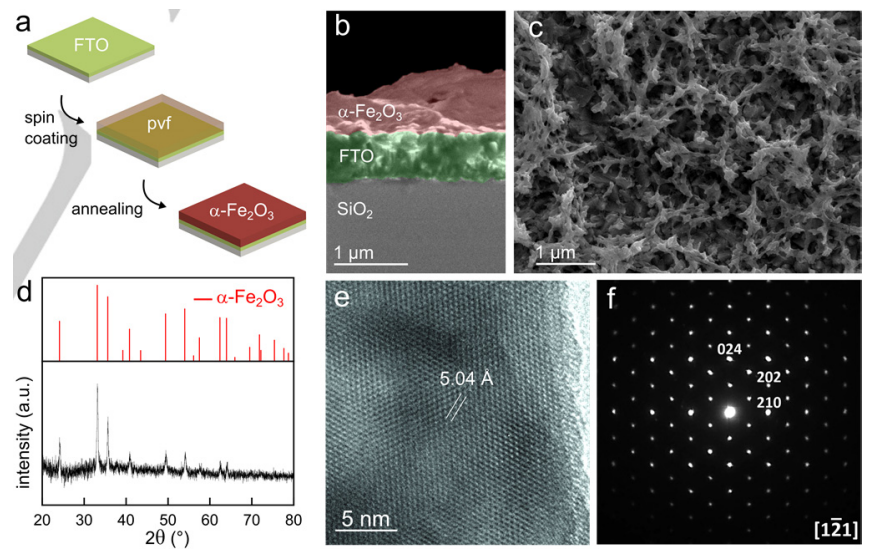

Figure 1. a) Scheme showing the method used to deposit hematite on FTO. b) Colored SEM image showing a cross-section of the hematite deposited on FTO. c) SEM image showing a top view of the hematite coating on FTO. d) XRD pattern of the deposited layer (black line), the red lines indicate the peaks position and relative intensity for hematite (ICSD \#15840). e) High-resolution TEM image of the prepared hematite layer, the distance between the (210) planes is indicated. f) [1 $1 \overline{2} 1]$ zone axis SAED patterns recorded on hematite.

Our hematite precursor is poly(vinylferrocene) (pvf), a Fecontaining polymer, dissolved in tetrahydrofuran (THF), which was spin-coated onto FTO slides and subsequently annealed, as shown in Figure 1a. A similar approach was previously employed by our group, however, with a low annealing temperature $\left(300^{\circ} \mathrm{C}\right)$ in order to deposit amorphous catalytic $\mathrm{FeO}_{x}$ layers. ${ }^{[49]}$ In the present work, we wanted to assess the feasibility of growing semiconductor films, we thus employed a higher annealing 
temperature for generating crystalline hematite. The effect of the annealing temperature and the number of spin-coating/annealing cycles was evaluated by PEC experiments shown in Figure S3. In agreement with these tests, we decided to use 3 cycles of spincoating and an annealing temperature of $480{ }^{\circ} \mathrm{C}$, which will be kept constant for the rest of this article. The crystalline nature of the so-synthesized layers is clearly revealed from the X-ray diffraction (XRD) pattern of Figure $1 \mathrm{~d}$ as all measured diffraction peaks can be assigned to the structure of hematite (ICSD \#15840) The surfaces were then analyzed by electron microscopy. Scanning electron microscopy (SEM) (Figure 1b,c) revealed that the hematite layer formed a porous crust having a thickness in the range of $\sim 1 \mu \mathrm{m}$. Transmission electron microscopy (TEM) imaging (Figure 1e) and selected area electron diffraction (SAED) pattern (Figure 1f) further confirmed the crystallinity of the deposited layer.
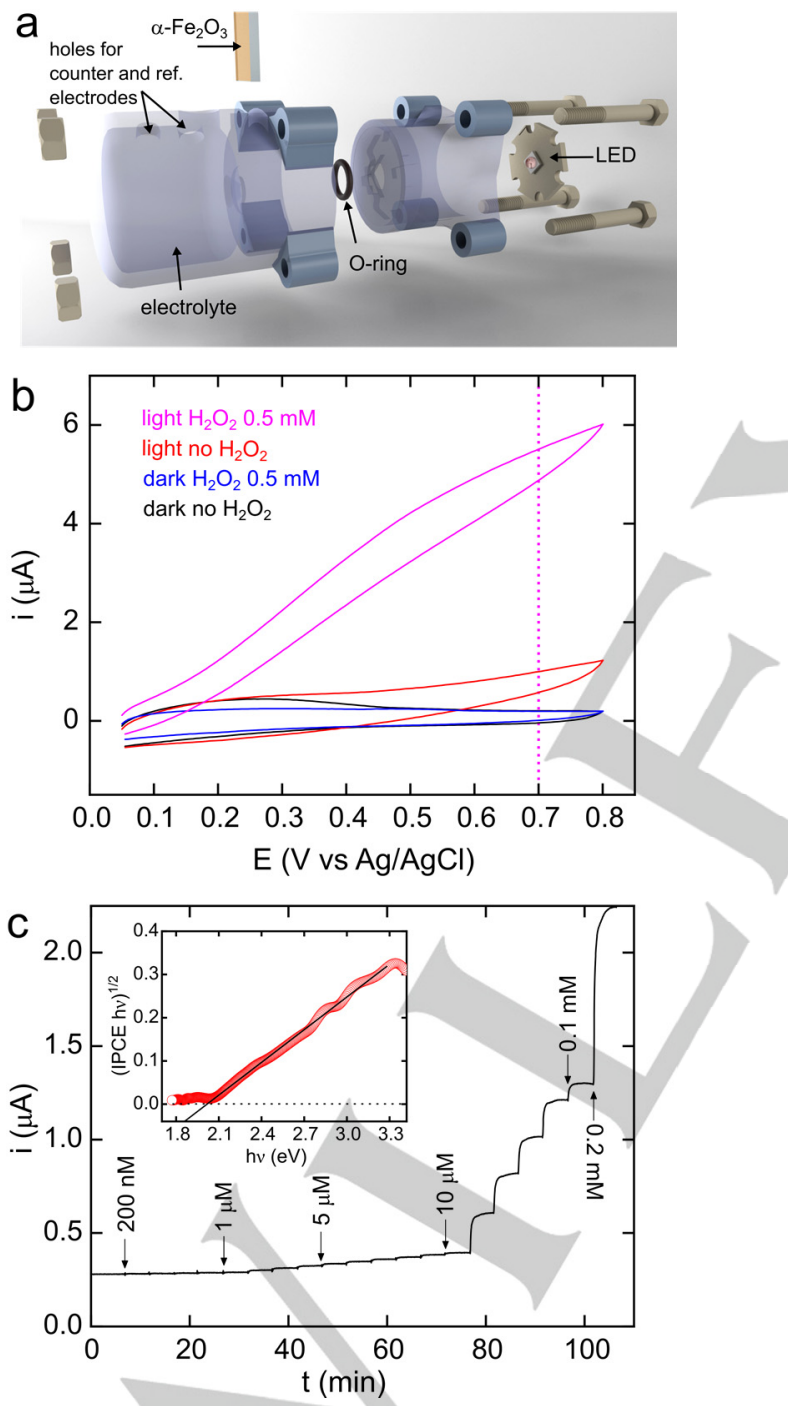

Figure 2. a) 3D view of the cell used for the PEC experiments. b) $\mathrm{CV}$ s recorded in phosphate buffer under illumination $(370 \mathrm{~nm})$ in the presence of $0.5 \mathrm{mM} \mathrm{H}_{2} \mathrm{O}_{2}$ (pink), in the absence of $\mathrm{H}_{2} \mathrm{O}_{2}$ (red) as well as in the dark in the presence of 0.5 $\mathrm{mM} \mathrm{H} \mathrm{O}_{2}$ (blue) and in the absence of $\mathrm{H}_{2} \mathrm{O}_{2}$ (black). c) Chronoamperometry recorded during a $\mathrm{PEC}$ sensing experiment at $0.7 \mathrm{~V}$ in phosphate buffer. Inset: Tauc plot recorded in phosphate buffer at $0.7 \mathrm{~V}$ in the presence of $0.5 \mathrm{mM} \mathrm{H}_{2} \mathrm{O}_{2}$ with backside illumination. The red circles are experimental points and the black line is a linear fit.
We manufactured a PEC cell by 3D printing, which integrates a light source (a $370 \mathrm{~nm}$ LED), as shown in Figure 2a. In this system, the electrolyte volume is $12 \mathrm{~mL}$ and the photoanode is illuminated from the backside (through the FTO), which is a configuration beneficial in terms of cell architecture (allowing for miniaturization and minimization of optical losses) but also in terms of photoresponse as this configuration improves electron collection, thus, photocurrent (Figure S3). ${ }^{[50]}$ Our FTO/ $\alpha-\mathrm{Fe}_{2} \mathrm{O}_{3}$ surfaces were then employed as photoanodes in this cell and assessed for the photoelectrochemical oxidation of $\mathrm{H}_{2} \mathrm{O}_{2}$, which occurs through the following reaction: ${ }^{[26]}$

$$
\mathrm{H}_{2} \mathrm{O}_{2}(\mathrm{I})+2 \mathrm{~h}^{+} \rightarrow 2 \mathrm{H}^{+}(\mathrm{aq})+\mathrm{O}_{2}(\mathrm{~g})
$$

Although this has not been studied in the context of this article, one might also consider that Fenton-type processes can occur at the solid/liquid interface in these conditions. The cyclic voltammetry (CV) curves shown in Figure $2 \mathrm{~b}$ and Figure $\mathrm{S} 4$ clearly demonstrate the effects of illumination and $\mathrm{H}_{2} \mathrm{O}_{2}$. Indeed, only small currents are measured in the dark regardless of the presence of $\mathrm{H}_{2} \mathrm{O}_{2}$ (black and blue $\mathrm{CVs}, \mathrm{i}=0.2 \mu \mathrm{A}$ at $0.7 \mathrm{~V}$ ) while illumination promotes the generation of higher currents. The photocurrent recorded in the absence of $\mathrm{H}_{2} \mathrm{O}_{2}$ (red $\mathrm{CV}, \mathrm{i}=1 \mu \mathrm{A}$ at $0.7 \mathrm{~V}$ ) is attributed to water oxidation and the much larger photocurrent measured in the presence of $0.5 \mathrm{mM} \mathrm{H}_{2} \mathrm{O}_{2}$ (pink $\mathrm{CV}$, $i=5.5 \mu \mathrm{A}$ at $0.7 \mathrm{~V}$ ) is attributed to reaction (1). The shape of the voltammograms is in good agreement with what has been previously reported for reaction (1) at hematite photoanodes. ${ }^{[26]}$ Control experiments (Figure S5) performed on bare FTO showed the inactivity of that surface for reaction (1) as well as its negligible photoelectrochemical activity. Overall, these CV results suggest that dark electrochemical oxidation is inefficient and that illuminated $\mathrm{FTO} / \alpha-\mathrm{Fe}_{2} \mathrm{O}_{3}$ surfaces have a strong potential for the electrochemical detection of $\mathrm{H}_{2} \mathrm{O}_{2}$.

The PEC properties of our hematite surfaces were also assessed by photocurrent spectroscopy. The results obtained at $0.7 \mathrm{~V}$ are shown in a Tauc plot (inset of Figure 2c) which reveals that the photoelectrochemical bandgap of our material is $2 \mathrm{eV}$, in good agreement with the reported values for hematite. ${ }^{[11,42]}$ Next, we explored the possibility of using these surfaces for $\mathrm{H}_{2} \mathrm{O}_{2}$ PEC sensing in the 3D printed cell (Figure 2a) under illumination at a constant potential of $0.7 \mathrm{~V}$. After equilibration of the electrochemical signal, micro volumes of $\mathrm{H}_{2} \mathrm{O}_{2}$ were sequentially injected into the cell and the current was simultaneously recorded. As shown in Figure 2c, the photocurrent increased with the injected volume, allowing for instantaneous sensing of the $\mathrm{H}_{2} \mathrm{O}_{2}$ concentration.

The detailed PEC sensing is shown in the chronoamperometry and calibration curves of Figure 3. As it can be observed in Figure $3 a$, we could detect a $\mathrm{H}_{2} \mathrm{O}_{2}$ concentration as low as $200 \mathrm{nM}$ even if this value falls below the range of the theoretical limit of detection (LOD), generally defined for a signal-to-noise ratio $(\mathrm{S} / \mathrm{N})$ of 3. This range is represented by pink dotted lines in Figure 3a and $3 d$ (we took the $N$ value as 2 times the noise standard deviation, as shown in Figure S6) and based on Figure 3a, our LOD $=400 \mathrm{nM}$. The calibration curve, in which the output signal is defined as the photocurrent measured in the presence of $\mathrm{H}_{2} \mathrm{O}_{2}$ minus the initial photocurrent $\left(\mathrm{i}-\mathrm{i}_{0}\right)$, is shown in three concentration ranges in Figures $3 d-f$. Linear fitting shows that the photoresponse is linear up to $50 \mu \mathrm{M}$ with a sensitivity of $10.69 \mathrm{nA}$ $\mu M^{-1}\left(R^{2}=0.99952\right)$. 

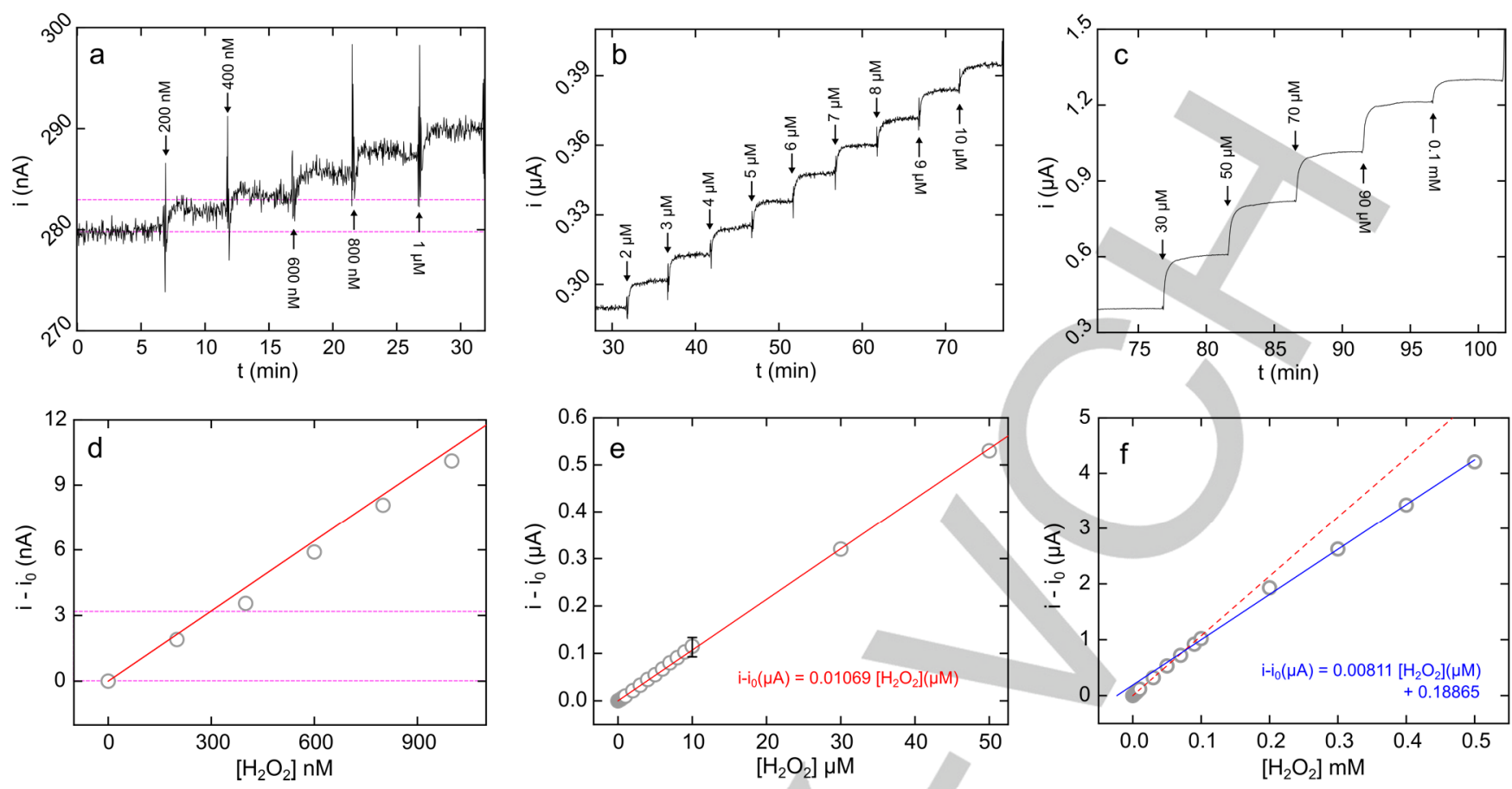

Figure 3. a-c) Chronoamperometry curves of $\mathrm{H}_{2} \mathrm{O}_{2} \mathrm{PEC}$ sensing measured at $0.7 \mathrm{~V}$ under illumination with different $\mathrm{H}_{2} \mathrm{O}_{2}$ concentrations ranges. From a) 0 to 1 $\mu \mathrm{M}, \mathrm{b}) 1$ to $10 \mu \mathrm{M}$ and c) 0.01 to $0.1 \mathrm{mM}$. d-f) Calibration curves, presented as $\mathrm{i}-\mathrm{i}_{\mathrm{o}}$ as a function of the $\mathrm{H}_{2} \mathrm{O}_{2}$ concentration in different ranges. From d) 0 to $1 \mu \mathrm{M}$, e) 0 to $50 \mu \mathrm{M}$ and f) 0 to $0.5 \mathrm{mM}$. The grey circles are experimentally determined points, the red line is a linear fit including the experimental data recorded from 0 to $50 \mu \mathrm{M}$ and the blue line is a linear fit including the experimental data recorded from $50 \mu \mathrm{M}$ to $0.5 \mathrm{mM}$. The error bar shown in panel e) at $10 \mu \mathrm{M}$ has been determined from the measurements performed on 6 independent surfaces (see Figure $4 a$ ) and equals 2 standard deviations. The pink dotted lines in panel a) and d) show the range of output photocurrent corresponding to a $\mathrm{S} / \mathrm{N}$ ratio of 3 .

After that concentration (the chronoamperometry is shown in Figure S7), the output signal deviates from linearity (dashed red curve in Figure 3f) and follows the following function: 0.00811 $\left[\mathrm{H}_{2} \mathrm{O}_{2}\right](\mu \mathrm{M})+0.18865\left(\mathrm{R}^{2}=0.99837\right.$, blue curve in Figure 3f). The performance of PEC sensors is highly dependent on multiple experimental conditions intrinsic to the light source or to the surface and thus it is difficult to directly compare the performance of our system with the one reported by others. Keeping this in mind, we gathered in Table 1 benchmark values reported for $\mathrm{H}_{2} \mathrm{O}_{2}$ PEC sensors based on several semiconductor photoelectrodes. It shows that our LOD is lower than the ones obtained on $\mathrm{BiVO}_{4},{ }^{[34,35]} \mathrm{Si}^{\left[{ }^{[36]}\right.} \mathrm{CuO}^{[38]}$ and $\mathrm{CdS}^{[39]}$-based photoelectrodes. In addition, our linear range, which spans 2 orders of magnitudes in concentration, is large and greater than the ones reported for $\mathrm{TiO}_{2},{ }^{[28]} \mathrm{WO}_{3},{ }^{[31]} \mathrm{ZnO}^{[32,33]}$ and $\mathrm{Cu}_{2} \mathrm{O}^{[37]}$-based photoelectrodes. It is also interesting to note that systems based on the $\mathrm{TiO}_{2} / \mathrm{CdS}$ heterojunction ${ }^{[29,30]}$ exhibit a lower LOD and a wide linear range, however, these systems may have disadvantages from an environmental point of view.

The reproducibility of our preparation and sensing method was tested by comparing the output signal recorded for $10 \mu \mathrm{M} \mathrm{H}_{2} \mathrm{O}_{2}$ on 6 independently-prepared photoanodes. The results, presented in Figure $4 \mathrm{a}$, show relatively good reproducibility (standard deviation $=0.02 \mu \mathrm{A}$ ) and an average value for $\mathrm{i}-\mathrm{i}_{0}$ of $0.11 \mu \mathrm{A}$, which is in good agreement with the sensitivity value previously determined (Figure $3 e$ ). The stability and the reusability of our photoanodes were evaluated by performing several sensing measurements with $10 \mu \mathrm{M} \mathrm{H}_{2} \mathrm{O}_{2}$ on the same photoanode several days apart. The results, shown in Figure 4b, demonstrate good stability since no variation of output signal was measured over a week of measurements.

Table 1. Performance reported for $\mathrm{H}_{2} \mathrm{O}_{2}$ PEC sensing on semiconductors-based photoelectrodes.

\begin{tabular}{|c|c|c|c|}
\hline semiconductor & linear range $(\mu \mathrm{M})$ & LOD $(\mu \mathrm{M})$ & reference \\
\hline $\mathrm{TiO}_{2}$ & $0.5-35$ & 0.18 & [28] \\
\hline $\mathrm{TiO}_{2} / \mathrm{CdS}$ & $1 \times 10^{-3}-20$ & $0.5 \times 10^{-3}$ & [29] \\
\hline $\mathrm{TiO}_{2} / \mathrm{CdS}$ & $0.1-10000$ & $2 \times 10^{-3}$ & [30] \\
\hline $\mathrm{WO}_{3}$ & $0.02-10$ & $3 \times 10^{-3}$ & [31] \\
\hline $\mathrm{ZnO} / \mathrm{C}_{3} \mathrm{~N}_{4}$ & $1.3 \times 10^{-3}-80 \times 10^{-3}$ & $0.38 \times 10^{-3}$ & [32] \\
\hline $\mathrm{ZnO}$ & $0.02-0.8$ & $2.4 \times 10^{-3}$ & [33] \\
\hline $\mathrm{BiVO}_{4}$ & $9.5-765$ & 1.59 & [34] \\
\hline $\mathrm{BiVO}_{4}$ & $50-1500$ & 8.5 & [35] \\
\hline $\mathrm{Si}$ & $10-60$ & 2.2 & [36] \\
\hline $\mathrm{Cu}_{2} \mathrm{O} / \mathrm{TiO}_{2}$ & $1-15$ & 0.15 & [37] \\
\hline $\mathrm{CuO}$ & $100-1000$ & 180 & [38] \\
\hline CdS & $25-1000$ & 19 & [39] \\
\hline CulnS $_{2}$ & $0.5-530$ & 0.47 & [40] \\
\hline$\alpha-\mathrm{Fe}_{2} \mathrm{O}_{3}$ & $0.2-50$ & 0.4 & this work \\
\hline
\end{tabular}


The effect of light on the output signal was studied by chronoamperometry using intermittent illumination. As it can be seen in Figure 4c, the current was directly controlled by the illumination and it was instantaneously switched off when illumination was stopped. This shows the feasibility of making a fast background signal, which can be very convenient in sensing devices. Finally, we studied the effect of several typical potential organic and inorganic interfering salts (at a concentration of 10 $\mu \mathrm{M})$, namely, citric acid (CA), oxalic acid (OA), tartaric acid (TA), $\mathrm{Na}_{2} \mathrm{SO}_{4}$ and $\mathrm{KNO}_{3}{ }^{[31]}$ The chronoamperometry shown in Figure $4 \mathrm{~d}$ reveal that the presence of these molecules does not impede with the $\mathrm{H}_{2} \mathrm{O}_{2}$ detection signal, suggesting a good selectivity towards $\mathrm{H}_{2} \mathrm{O}_{2}$.
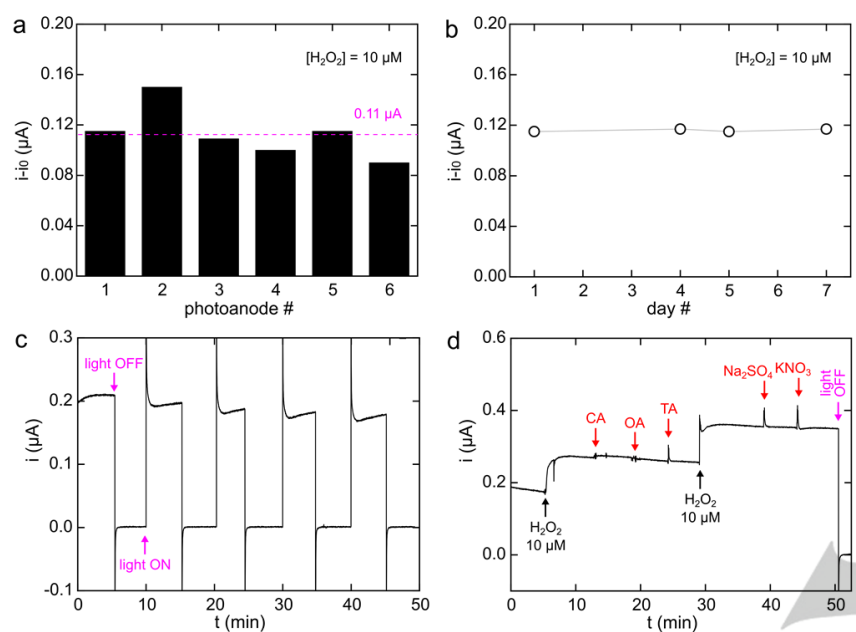

Figure 4. a) Graph showing the output photoresponse obtained for the PEC sensing of $10 \mu \mathrm{M} \mathrm{H}_{2} \mathrm{O}_{2}$ on 6 independently-prepared hematite photoanodes. b) Output photoresponse measured with the same hematite photoanode for the PEC sensing of $10 \mu \mathrm{M} \quad \mathrm{H}_{2} \mathrm{O}_{2}$ performed several days apart. c) Chronoamperometry recorded under intermittent LED illumination in the presence of $10 \mu \mathrm{M} \mathrm{H} \mathrm{H}_{2}$. d) Chronoamperometry showing the effect of interfering compounds on $\mathrm{PEC}$ sensing.

In conclusion, we reported a simple method to deposit hematite layers on FTO and we employed these surfaces for the PEC sensing of $\mathrm{H}_{2} \mathrm{O}_{2}$ in a $3 \mathrm{D}$ printed photoelectrochemical cell. The system is robust and we were able to experimentally detect $\mathrm{H}_{2} \mathrm{O}_{2}$ at concentration as low as $200 \mathrm{nM}$ at a physiological $\mathrm{pH}$ with a linear photoresponse up to $50 \mu \mathrm{M}$. Although more research is still needed to improve this system (i.e. optimization of the layer, study of the effect of a large panel of oxidizable molecules), it is promising, first because $\mathrm{H}_{2} \mathrm{O}_{2}$ is of great interest in medicinal, environmental and industrial applications, and, second, because hematite is cheap and a good candidate for spatially-resolved PEC sensing. ${ }^{[15,17]}$

\section{Acknowledgements}

This work was supported by CNRS and the Université de Rennes 1. AZM \& SAADE Association is fully acknowledged for financial support. Dr. Olivier Jeannin and Kiseok Oh are acknowledged for helpful discussions.
Keywords: photoelectrochemistry $\cdot$ photoelectrochemical sensing $\bullet$ photoelectrochemical detection $\bullet$ hydrogen peroxide $\bullet$ hematite

[1] P. A. MacCarthy, A. M. Shah, Coron. Artery Dis. 2003, 14, 109.

[2] E. Suraniti, S. Ben-Amor, P. Landry, M. Rigoulet, E. Fontaine, S. Bottari, A. Devin, N. Sojic, N. Mano, S. Arbault, Angew. Chemie Int. Ed. 2014, 53,6655 .

[3] W. J. Cooper, R. O. D. G. Zika, Science 1983, 220, 711.

[4] M. Song, J. Wang, B. Chen, L. Wang, Anal. Chem. 2017, 89, 11537.

[5] N. V Klassen, D. Marchington, H. C. E. McGowan, Anal. Chem. 1994, 66 2921.

[6] R. F. P. Nogueira, M. C. Oliveira, W. C. Paterlini, Talanta 2005, 66, 86.

[7] F. Rezende, R. P. Brandes, K. Schröder, Antioxid. Redox Signal. 2017 29, 585.

[8] Y. B. Tsaplev, J. Anal. Chem. 2012, 67, 506.

[9] W. Chen, S. Cai, Q.-Q. Ren, W. Wen, Y.-D. Zhao, Analyst 2012, 137, 49.

[10] R. Gulaboski, V. Mirčeski, R. Kappl, M. Hoth, M. Bozem, J. Electrochem. Soc. 2019, 166, G82.

[11] R. Koncki, Crit. Rev. Anal. Chem. 2002, 32, 79.

[12] I. Willner, F. Patolsky, J. Wasserman, Angew. Chemie Int. Ed. 2001, 40, 1861.

[13] J. Shu, D. Tang, Anal. Chem. 2019, doi. org/10.1021/acs.analchem.9b04199.

[14] S. Licht, N. Myung, Y. Sun, Anal. Chem. 1996, 68, 954.

[15] Y. B. Vogel, J. J. Gooding, S. Ciampi, Chem. Soc. Rev. 2019, 48, 3723.

[16] I. T. Rodriguez, A. J. Borrill, G. O'Neil, 2019, DO 10.26434/chemrxiv.10246820.v1.

[17] D. Seo, S. Y. Lim, J. Lee, J. Yun, T. D. Chung, ACS Appl. Mater Interfaces 2018, 10, 33662.

[18] J. Wang, J. Long, Z. Liu, W. Wu, C. Hu, Biosens. Bioelectron. 2017, 91, 53.

[19] H. Dai, S. Zhang, Z. Hong, Y. Lin, Anal. Chem. 2016, 88, 9532.

[20] W.-W. Zhao, J.-J. Xu, H.-Y. Chen, Chem. Soc. Rev. 2015, 44, 729.

[21] W.-W. Zhao, J.-J. Xu, H.-Y. Chen, Anal. Chem. 2018, 90, 615.

[22] W.-W. Zhao, J.-J. Xu, H.-Y. Chen, TrAC Trends Anal. Chem. 2016, 82, 307.

[23] L. Wang, D. Han, S. Ni, W. Ma, W. Wang, L. Niu, Chem. Sci. 2015, 6, 6632.

[24] J. Tang, Y. Wang, J. Li, P. Da, J. Geng, G. Zheng, J. Mater. Chem. A 2014, 2, 6153.

[25] F. Liu, P. Wang, Q. Zhang, Z. Wang, Y. Liu, Z. Zheng, X. Qin, X. Zhang, Y. Dai, B. Huang, Electroanalysis 2019, 31, 1809.

[26] H. Dotan, K. Sivula, M. Grätzel, A. Rothschild, S. C. Warren, Energy Environ. Sci. 2011, 4, 958.

[27] Y. Y. Avital, H. Dotan, D. Klotz, D. A. Grave, A. Tsyganok, B. Gupta, S Kolusheva, I. Visoly-Fisher, A. Rothschild, A. Yochelis, Nat. Commun. 2018, 9, 4060.

[28] D. Chen, H. Zhang, X. Li, J. Li, Anal. Chem. 2010, 82, 2253.

[29] W.-W. Zhao, P.-P. Yu, J.-J. Xu, H.-Y. Chen, Electrochem. Commun. 2011, 13, 495

[30] L. Li, B. Li, H. Liu, M. Li, B. Wang, J. Alloys Compd. 2020, 815, 152241.

[31] X. Zhang, L. Li, X. Peng, R. Chen, K. Huo, P. K. Chu, Electrochim. Acta 2013, 108, 491

[32] X. Xi, J. Li, H. Wang, Q. Zhao, H. Li, Microchim. Acta 2015, 182, 1273.

[33] F. Khan, N. Akhtar, N. Jalal, I. Hussain, R. Szmigielski, M. Q. Hayat, H. B. Ahmad, W. A. El-Said, M. Yang, H. A. Janjua, Microchim. Acta 2019, 186, 127.

[34] M. Liu, Y.-X. Yu, W.-D. Zhang, Electroanalysis 2017, 29, 305.

[35] Z. Yu, S. Lv, R. Ren, G. Cai, D. Tang, Microchim. Acta 2017, 184, 799.

[36] H. Li, W. Hao, J. Hu, H. Wu, Biosens. Bioelectron. 2013, 47, 225.

[37] Z. Li, Y. Xin, Z. Zhang, Anal. Chem. 2015, 87, 10491.

[38] M. Rehosek, D. Mitoraj, M. Bledowski, R. Beranek, Electroanalysis 2016, $28,2327$.

[39] Z. Yue, W. Zhang, C. Wang, G. Liu, W. Niu, Mater. Lett. 2012, 74, 180

[40] S. Wang, Y. Zhu, X. Yang, C. Li, Electroanalysis 2014, 26, 573.

[41] A. G. Tamirat, J. Rick, A. A. Dubale, W.-N. Su, B.-J. Hwang, Nanoscale Horizons 2016, 1, 243 
[42] P. Sharma, J.-W. Jang, J. S. Lee, ChemCatChem 2019, 11, 157.

[43] Z. Li, C. Su, D. Wu, Z. Zhang, Anal. Chem. 2018, 90, 961.

[44] G. M. Ryu, M. Lee, D. S. Choi, C. B. Park, J. Mater. Chem. B 2015, 3, 4483.

[45] Y. Zhang, T. Cao, X. Huang, M. Liu, H. Shi, G. Zhao, Electroanalysis 2013, 25, 1787.

[46] X. Du, L. Dai, D. Jiang, H. Li, N. Hao, T. You, H. Mao, K. Wang, Biosens. Bioelectron. 2017, 91, 706.

[47] F. X. Wang, C. Ye, S. Mo, L. L. Liao, H. Q. Luo, N. B. Li, Sens. Actuators B Chem. 2019, 288, 202

[48] J. Tang, J. Li, Y. Zhang, B. Kong, Yiliguma, Y. Wang, Y. Quan, H. Cheng, A. M. Al-Enizi, X. Gong, G. Zheng, Anal. Chem. 2015, 87, 6703.

[49] H. Saada, R. Abdallah, B. Fabre, D. Floner, S. Fryars, A. Vacher, V. Dorcet, C. Meriadec, S. Ababou-Girard, G. Loget, ChemElectroChem 2019, 6, 613.

[50] P. S. Bassi, L. Xianglin, Y. Fang, J. S. C. Loo, J. Barber, L. H. Wong, Phys. Chem. Chem. Phys. 2016, 18, 30370. 


\section{COMMUNICATION}

\section{Entry for the Table of Contents}
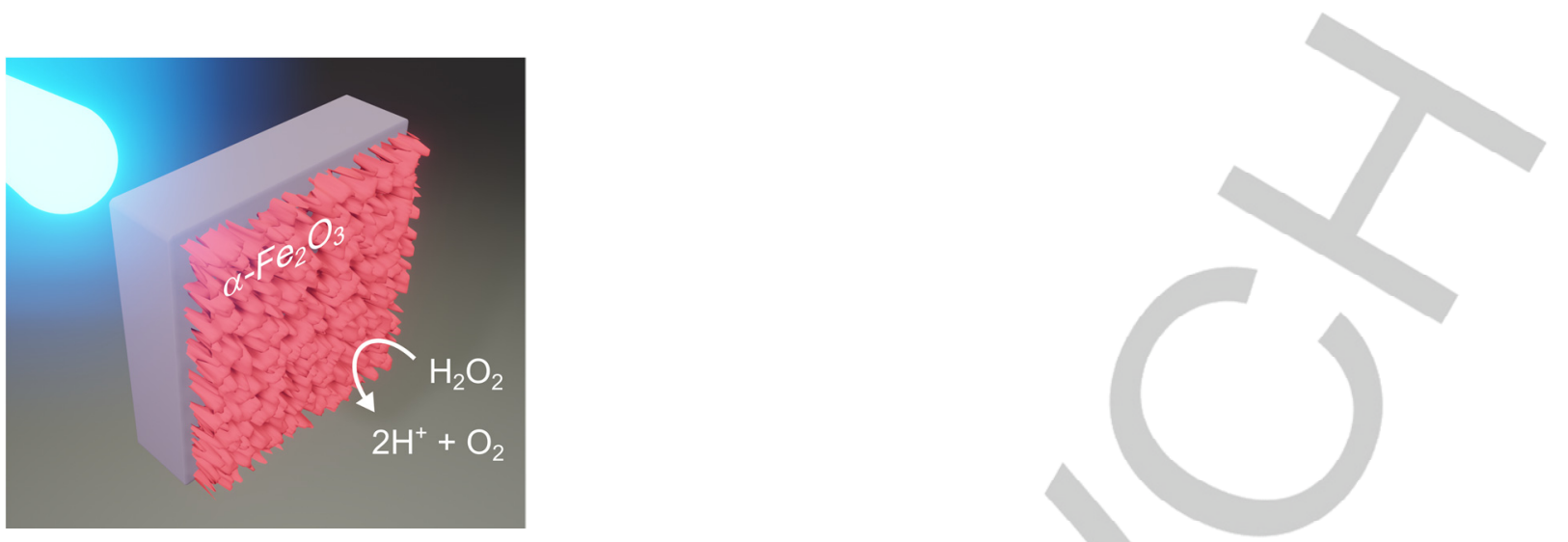

We report a straightforward method to prepare $\alpha-\mathrm{Fe}_{2} \mathrm{O}_{3}$ layers on fluorine-doped $\mathrm{SnO}_{2}$ and we use these surfaces in a $3 \mathrm{D}$ printed photoelectrochemical cell for the PEC sensing of $\mathrm{H}_{2} \mathrm{O}_{2}$. These systems exhibit a large linear range, a good reusability and allow to reliably detect $\mathrm{H}_{2} \mathrm{O}_{2}$ down to a sub-micromolar concentration.

Institute and/or researcher Twitter usernames: @chimie_ISCR 